\title{
EVALUATION OF VIDEO-OTOSCOPIC, RADIOGRAPHIC AND COMPUTED TOMOGRAPHIC EXAMINATIONS OF CATS AND DOGS WITH EAR DISEASES
}

\author{
Kurtulus Parlak ${ }^{1}$, Mustafa Yalcin², Hanifi Erol' ${ }^{3}$, Eyüp Tolga Akyol ${ }^{4}$, \\ Elgin Orcum Uzunlu ${ }^{1}$, Nuriza Zamirbekova ${ }^{1}$, Mustafa Arican ${ }^{1}$ \\ ${ }^{1}$ Department of Surgery, Faculty of Veterinary Medicine, \\ Selcuk University, 4225 Konya, Turkey \\ ${ }^{2}$ Department of Surgery, Faculty of Veterinary Medicine, \\ Cumhuriyet University, 58140 Sivas, Turkey \\ ${ }^{3}$ Department of Surgery, Faculty of Veterinary Medicine, \\ Erciyes University, 38250 Kayseri, Turkey \\ ${ }^{4}$ Department of Surgery, Faculty of Veterinary Medicine, \\ Balikesir University, 10145 Balikesir, Turkey
}

Received 25 August 2020; Received in revised form 19 December 2020; Accepted 8 February 2021

\begin{abstract}
The aim of this study was to evaluate the effectiveness of imaging techniques (video-otoscopy-VO, radiography-RTG, computed tomography-CT) in diagnosing ear diseases in cats and dogs. Seven cats and thirteen dogs diagnosed with ear diseases were used for the research. Clinical examination, VO, RTG and CT were performed. Three (42.9\%) unilateral otitis externa $(\mathrm{OE})$, three $(42.9 \%)$ unilateral otitis media $(\mathrm{OM})$, and one $(14.2 \%)$ bilateral otitis media $(\mathrm{OM})$ with $\mathrm{OE}$ were diagnosed in 7 cats. Five (38.4\%) unilateral OE, one (7.7\%) unilateral OM, four (30.8\%) bilateral OE, and three $(23.1 \%)$ bilateral $\mathrm{OM}$ with $\mathrm{OE}$ were diagnosed in 13 dogs. All diagnostic methods were determined to be highly efficient for the specified diagnosis. VO and RTG were confirmed as sufficiently effective for the diagnosis of OE. OE plays a major role in the etiopathogenesis of OM, and for this reason, RTG and CT are required diagnostic methods for this condition.
\end{abstract}

Key words: diagnostic imaging, ear diseases, cat, dog

\section{INTRODUCTION}

Otitis externa $(\mathrm{OE})$ is one of the most common ear problems, more frequently reported in dogs than in cats. Bacteria, fungi and parasites are the major etiological agents for numerous ear problems including OE $(1,2)$.

The most common bacterial agents for $\mathrm{OE}$ are Staphylococcus intermedius, Staphylococcus

Corresponding author: Dr. Kurtulus Parlak, $\mathrm{PhD}$

E-mail address: kparlak@selcuk.edu.tr

Present address: Department of Surgery, Faculty of Veterinary Medicine,

Selcuk University, 4225 Konya, Turkey

Phone: +905064574421

Copyright: (C) 2021 Parlak K. This is an open-access article published under the terms of the Creative Commons Attribution License which permits unrestricted use, distribution, and reproduction in any medium, provided the original author and source are credited.

Competing Interests: The authors have declared that no competing interests exist.

Available Online First: 26 February 2021

Published on: 15 March 2021

https://doi.org/10.2478/macvetrev-2021-0013 aureus, Pseudomonas aeruginosa, Proteus mirabilis, Klebsiella spp., Bacillus spp., Serratia spp., Corynebacterium spp. and Escherichia coli. Most of these agents (Staphylococcus spp., B-haemolytic Streptococcus spp., Proteus mirabilis, E. coli, Pseudomonas aeruginosa) are considered as normal ear flora. Otodectes cynotis is the most common parasite that causes OE in cats and $\operatorname{dogs}(3,4)$. Ear hematoma, incoordination, hearing problems and tympanic membrane perforation can appear during chronic otitis $(5,6)$. Otitis media $(\mathrm{OM})$ is defined as the accumulation of debris and exudate in bulla tympanica. Even though the prevalence of OM with chronic OE is usually $50-80 \%$ in dogs, it is often overlooked and misdiagnosed $(7,8)$. Chronic OE, inflammatory polyps, cholesteatoma and neoplasia are the general causes of OM. The following pathological findings can be observed on ear examination in cases with 
OM: thickened wall of bulla tympanica due to the accumulation of purulent fluid, the presence of soft tissue or thickened mucosa and new bone formation $(8,9,10)$. Clinical symptoms of inner ear disease are more pronounced and defined as a peripheral vestibular syndrome $(7,11)$.

External ear diseases may be easier to diagnose with physical examination compared to middle and inner ear conditions. Otoscopic or video-otoscopic examination (VO) should be performed for an indirect examination of the middle ear. In case of $\mathrm{OM}$, the tympanic membrane must be inspected for damage. Therefore, diagnostic imaging techniques (VO, ultrasonography, conventional radiography, $\mathrm{CT}$ and magnetic resonance imaging) have become widely used for the diagnosis of ear diseases $(7,11)$.

$\mathrm{VO}$ is a non-invasive method used for imaging of the external auditory canal and eardrum. It has a range of magnification lenses that allow detailed inspection of the tympanic membrane and external ear canal (7). The normal external ear canal is smooth, pale and has normal yellow or brown serum. The normal tympanic membrane is thin, light gray in color, and translucent $(12,13)$. In most cases, the inflammation affects the entire ear canal while, in some cases, it is localized in the horizontal or more commonly, in the vertical canal. Epidermal hyperplasia, nodules, tumors, polyps and foreign bodies can be easily visualized during the VO in the external ear canal. In these conditions, the external ear canal needs to be cleaned for better visualization $(14,15,16)$.

Radiography (RTG) was used for the assessment of ear cartilagecal cifications, neoplasms and bulla tympanica structure. The positioning of the patient is highly affecting the diagnostic accuracy of ear diseases. Hence, anesthesia is necessary for achieving appropriate positioning of the ear structures in animal patients (17). Dorso-ventral (DV), ventro-dorsal (VD), latero-lateral (LL), open-mouth rostro-caudal (RC) and latero-lateral oblique positionings are widely used in RTG ear examination $(17,18,19,20)$.

$\mathrm{CT}$ and magnetic resonance imaging (MRI) is also used for the examination of bulla tympanica (11, 19, 20). CT can be considered as preferred alternative to RTG in diagnosing middle ear diseases. The ear canal, middle ear and nasopharyngeal parts can be easily examined with CT under general anesthesia. Nasopharyngeal polyps and the determination of the degree of neoplasia can be identified with CT $(11,18)$.

The aim of the study was to compare the effectiveness of three imaging techniques (VO, RTG, $\mathrm{CT}$ ) in the diagnosis of ear diseases in cats and dogs.

\section{MATERIAL AND METHODS}

\section{Animals}

Seven cats and thirteen dogs (various breeds, age and sex) admitted to the Selcuk University, Faculty of Veterinary Medicine, Surgery Department, were included in the research. In all cases, the anamnestic data suggested ear disease. Positive diagnosis of ear disease was confirmed by the finding of earwax, ear discharge, redness of the auricle, unpleasant odor, head shaking, crusting and ear swelling. Animals that were presented with poor general health status were excluded from the investigation due to the necessity of undergoing sedation and/or anesthesia.

\section{Clinical examination}

General health status and physical examination were performed before ear inspection. The animals were placed in lateral recumbency for direct ear inspection (redness, discharge, odor, ear scratching, parasites, pinna control). The swab samples were taken from the ear canals for microbiological and parasitological examination.

\section{Video-otoscopic examination}

Video-otoscope (Firefly, DE550, USA) was used to visualize the external auditory canal and eardrum. The animals were sedated and restraint during the VO examination (Xylazine, Bayer, Germany, (1-2 mg/kg, IM)). The obtained images were recorded for later evaluation. Flexible forceps were used to remove foreign mass from the external canal.

\section{Radiographic examination}

All animals were sedated before the radiographic examination. An X-ray device and CR were used (SIEMENS, Sp-HF-4.0 Ralco Spain; Imago, Abbiategrasgenuso, Milano; Regius Model 110 Konica, Minolta). X-ray images were taken in various patient positions depending on the individual case (LL, LL oblique, VD, DV, RC, open-mouth RC).

\section{Computed tomographic examination}

Single-section computed tomography was used (Asteion, Toshiba Medical Systems Corporation, Japan). During the examination, the animals were subjected to propofol (4-6 mg/kg, IV, Lipuro 1\%, Germany) preventing anxiety and movement. Tomographic imaging was performed using a cross-sectional range of $3 \mathrm{~mm}$ in the DV position using $120 \mathrm{kV}, 150 \mathrm{~ms}$ for double scanning, and $120 \mathrm{kV}$, $100 \mathrm{~ms}$ for helical scanning. 


\section{RESULTS}

VO, RTG and CT findings of 7 cats and 13 dogs diagnosed with various ear conditions are shown in Table 1 and Fig. 1-4. All six cats of mixed breed (85.7\%) and four Golden Retriever dogs (30.7\%) were positively diagnosed with an ear condition.
Three $(42.9 \%)$ unilateral OE, three $(42.9 \%)$ unilateral OM, and one (14.2\%) bilateral OM with OE was diagnosed in 7 cats. Five $(38.4 \%)$ unilateral OE, one $(7.7 \%)$ unilateral OM, four $(30.8 \%)$ bilateral $\mathrm{OE}$, and three $(23.1 \%)$ bilateral OM with OE were diagnosed in 13 dogs (Table 1).

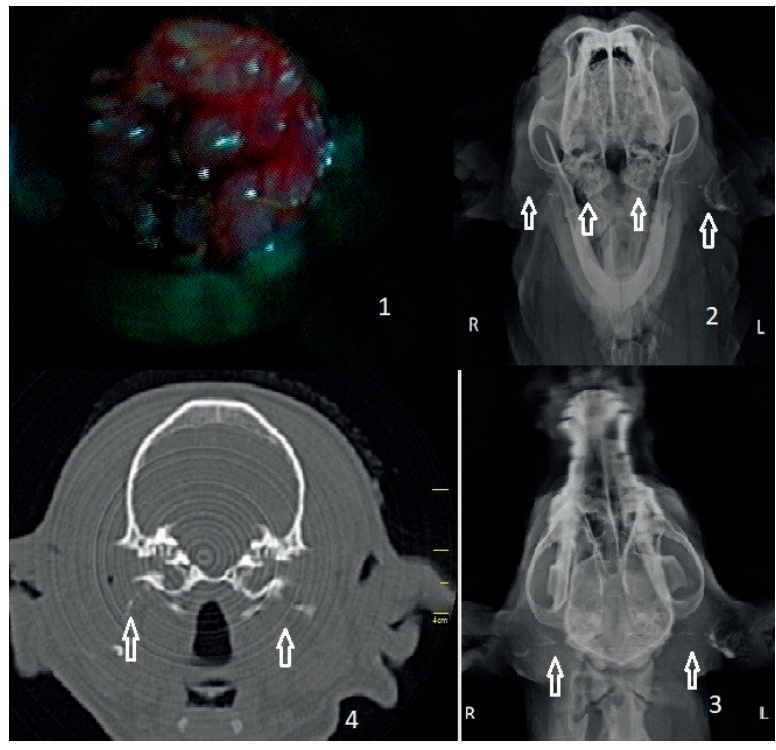

Figure 1. Case 7: bilateral chronic otitis externa and related otitis media, video-otoscopic image (1), open-mouth rostro-caudal radiography (2), ventro-dorsal radiography (3), CT image (4)

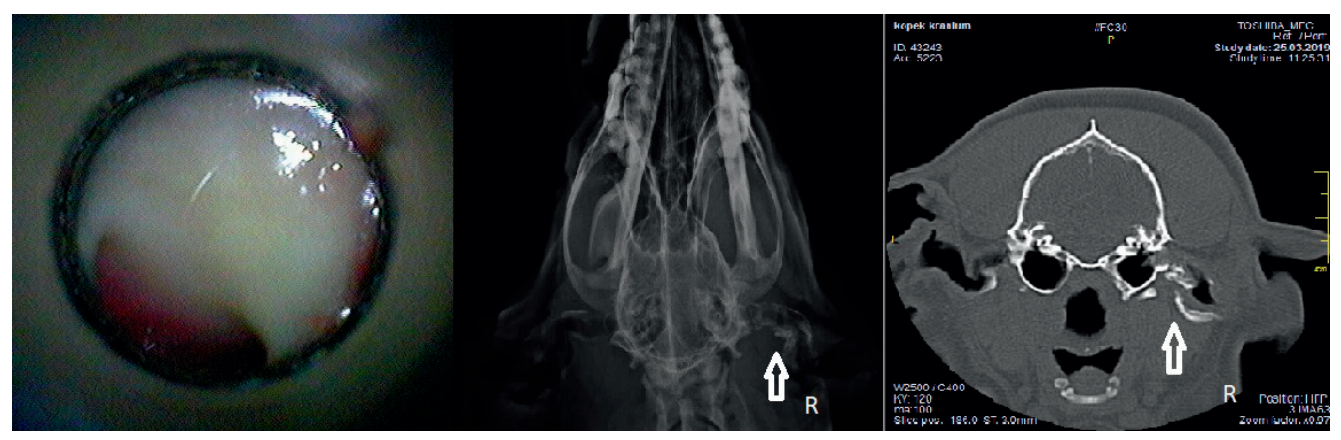

Figure 2. Case 10: right otitis externa (arrow), video-otoscopic, radiographic and computed tomographic image (left to right)

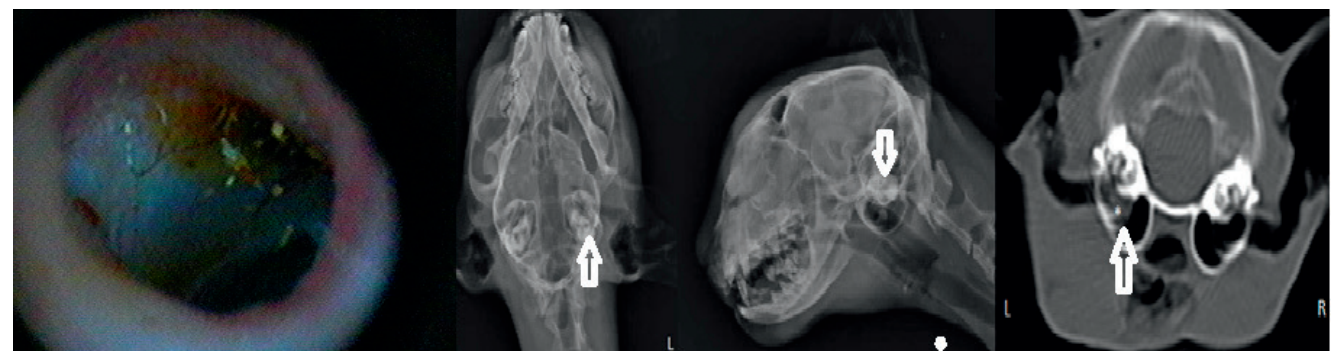

Figure 3. Case 8: left otitis media, (left to right) ventro-dorsal, latero-lateral oblique and CT image 


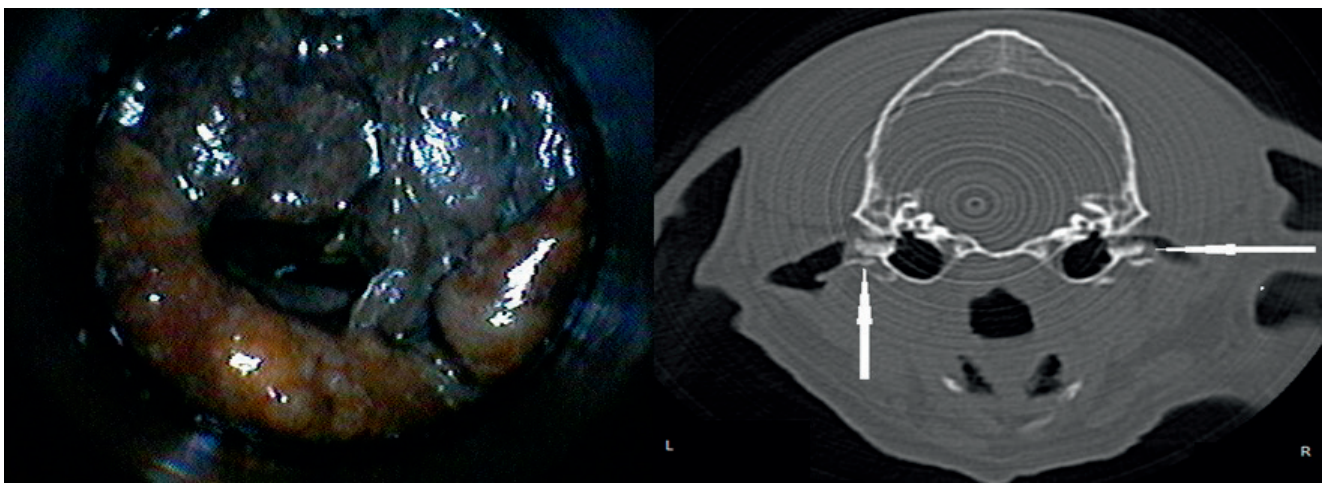

Figure 4. Case 2: otitis externa in the right and left ear. Video-otoscope (left) and CT image (right)

Table 1. Signalements and diagnosed ear problems of the cases

\begin{tabular}{|c|c|c|c|c|c|c|}
\hline Cases & Species & Breed & $\begin{array}{l}\text { Age } \\
\text { (Year) }\end{array}$ & Gender & $\begin{array}{l}\text { Diagnosis } \\
\text { (OE - otitis externa } \\
\text { OM - otitis media) }\end{array}$ & $\begin{array}{c}\text { Diagnostic Method } \\
\text { (VO-Video-Otoscopy } \\
\text { CT - Computed Tomographic) }\end{array}$ \\
\hline 1 & Dog & $\begin{array}{l}\text { Maltese } \\
\text { Terrier }\end{array}$ & 8 & 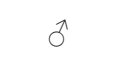 & Bilateral OE & $\begin{array}{l}\mathrm{VO} \\
\mathrm{CT}\end{array}$ \\
\hline 2 & Dog & $\begin{array}{l}\text { Golden } \\
\text { Retriever }\end{array}$ & 5 & q & Bilateral OE & $\begin{array}{l}\mathrm{VO} \\
\mathrm{CT}\end{array}$ \\
\hline 3 & Cat & Mixed & 3 & q & Unilateral (left) OM & $\begin{array}{l}\text { RTG } \\
\text { CT }\end{array}$ \\
\hline 4 & Cat & Mixed & 2 & q & Unilateral (right) $\mathrm{OE}$ & $\begin{array}{l}\mathrm{VO} \\
\mathrm{CT}\end{array}$ \\
\hline 5 & Cat & Mixed & 1 & 우 & Unilateral (right) $\mathrm{OE}$ & VO \\
\hline 6 & Cat & Mixed & 1,5 & $\sigma^{\lambda}$ & Unilateral (right) $\mathrm{OM}$ with $\mathrm{OE}$ & $\begin{array}{l}\text { VO } \\
\text { RTG } \\
\text { CT }\end{array}$ \\
\hline 7 & Dog & $\begin{array}{l}\text { Cocker } \\
\text { Spaniel }\end{array}$ & 9 & $\sigma^{\pi}$ & Bilateral OM with OE & $\begin{array}{l}\text { VO } \\
\text { RTG } \\
\text { CT }\end{array}$ \\
\hline 8 & Cat & Mixed & 1,5 & q & Unilateral (left) OM & $\begin{array}{l}\mathrm{VO} \\
\mathrm{CT}\end{array}$ \\
\hline 9 & Cat & Mixed & 3,5 & 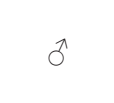 & Unilateral (right) $\mathrm{OE}$ & $\begin{array}{l}\text { VO } \\
\text { RTG } \\
\text { CT }\end{array}$ \\
\hline 10 & Dog & $\begin{array}{l}\text { Golden } \\
\text { Retriever }\end{array}$ & 4 & $\widehat{0}$ & Unilateral (right) $\mathrm{OE}$ & $\begin{array}{l}\text { VO } \\
\text { RTG } \\
\text { CT }\end{array}$ \\
\hline 11 & Dog & Pug & 5 & o & Bilateral OM with OE & $\begin{array}{l}\text { VO } \\
\text { RTG } \\
\text { CT }\end{array}$ \\
\hline 12 & Dog & $\begin{array}{l}\text { German } \\
\text { Shepherd }\end{array}$ & 4,5 & $\sigma^{\lambda}$ & Bilateral OE & $\begin{array}{l}\text { VO } \\
\text { RTG } \\
\text { CT }\end{array}$ \\
\hline 13 & Dog & $\begin{array}{l}\text { Cocker } \\
\text { Spaniel }\end{array}$ & 7 & $0^{2}$ & Bilateral OM with OE & $\begin{array}{l}\text { VO } \\
\text { RTG } \\
\text { CT }\end{array}$ \\
\hline 14 & Cat & $\begin{array}{l}\text { British } \\
\text { Shorthair }\end{array}$ & 3 & $\hat{0}$ & Unilateral (left) OM & $\mathrm{CT}$ \\
\hline 15 & Dog & $\begin{array}{l}\text { Golden } \\
\text { Retriever }\end{array}$ & 4 & q & Unilateral (right) $\mathrm{OE}$ & $\begin{array}{l}\text { VO } \\
\text { RTG }\end{array}$ \\
\hline 16 & Dog & $\begin{array}{l}\text { German } \\
\text { Shepherd }\end{array}$ & 2 & $\sigma^{2}$ & Unilateral (left) OM & $\mathrm{CT}$ \\
\hline 17 & Dog & $\begin{array}{l}\text { Golden } \\
\text { Retriever }\end{array}$ & 1 & $\hat{\sigma}$ & Unilateral (left) OE & $\mathrm{VO}$ \\
\hline 18 & Dog & $\begin{array}{l}\text { Maltese } \\
\text { Terrier }\end{array}$ & 9 & $\widehat{0}$ & Bilateral OE & VO \\
\hline 19 & Dog & $\begin{array}{l}\text { English } \\
\text { Setter }\end{array}$ & 3 & ठ & Unilateral (right) $\mathrm{OE}$ & $\mathrm{VO}$ \\
\hline 20 & Dog & Pointer & 2 & $\hat{\sigma}$ & Unilateral (right) $\mathrm{OE}$ & VO \\
\hline
\end{tabular}




\section{Clinical examination}

Microbiological analysis of the swab samples revealed the presence of yeast, fungus, $\beta$-hemolytic Streptococcus spp., Proteus mirabilis, Penicillium. Also, Otodectes cynotis was detected in 2 cats (case 4 and 6) after parasitological examination of the samples.

\section{Video-otoscopic examination}

The external ear canal was hemorrhagic and inflamed due to severe $\mathrm{OE}$ in few cases (cases 6, 7,12 ). Therefore, the eardrum could not be easily visualized. OM was detected by RTG and CT examination in several cases (case 3, 8, 14, 16), although there was no problem in the external ear canal.

\section{Radiographic examination}

RTG examination revealed severe chronic OE in 3 cases (cases 7, 13, 15). The chronic proliferation and calcified areas were visualized due to the excessive inflammation in the external ear canal, although the tympanic walls were symmetrical with no abnormal structure. The diagnosis of OM was easier with CT.

\section{Computed tomographic examination}

CT examination of the external auditory canal showed pathological signs in the patients with severe OE. However, there were no abnormal findings detected in acute and mild cases. The eardrum and tympanic bulla were easily visualized.

\section{DISCUSSION}

$\mathrm{OE}$ is one of the most common ear diseases in cats and dogs. In an epidemiological study, Tang et al. (21) reported that $84.62 \%$ of 221 dogs with ear problems were diagnosed with OE. In our study, OE rates were $57.10 \%$ in cats and $84.61 \%$ in dogs. This confirms the wide prevalence of $\mathrm{OE}$ in dogs.

$\mathrm{VO}$ is a useful and effective tool in the diagnosis of ear problems. It provides direct visualization of the external ear canal via magnification and the detailed structures of the ear canal. It reduces the risk of iatrogenic damage to the structures of the middle ear $(14,22)$. Pathological conditions in the external canal were easily visualized in 16 cases by VO. However, in two cases (cases 1 and 5), the diagnosed $\mathrm{OE}$ was not confirmed on the RTG examination. In cases 7 and 11, OE was diagnosed both on VO and RTG examinations. When comparing RTG findings, the radiopaque areas in the normal ear canals were replaced by radiolucent areas in affected ear canals. Calcifications and thickening of the external canal were easily visualized on RTG, especially in cases with chronic otitis. VO, compared to RTG or CT, was highly effective in acute $\mathrm{OE}$ cases by allowing direct visualization of the ear canal. However, chronic inflammatory processes of the external auditory canal which are manifested by narrowing due to hyperplasia, hemorrhagia and rigidity due to ulceration, tympanic membrane rupturing and disruption of the hair structure, cause limitations in imaging with the VO method. The unaffected ear canal is a sensitive structure, and therefore, VO examination should be avoided if it causes discomfort. Dogs may avoid this procedure if it is accompanied by discomfort.

OE was confirmed by VO and CT in cases 1-4, 6-13, and 15. However, several cases (cases 5, 17, 18,19 and 20) that were confirmed on VO could not be visualized on CT. These cases were inacute stage with small pathomorphological changes and were not significantly detectable on CT.

It has been reported that due to the complex skull and bone structure in dogs and cats, RTG imaging may be compromised by super imposition. This may affect the accurate detection and visualization in structural changes of bulla tympanica (23, 24). Remedios et al. (23) reported that 25\% of 19 surgically confirmed cases of OM were misdiagnosed by RTG, hence concluding that it was not a sufficiently sensitive method for diagnosing this condition. This was confirmed in a study by Love et al. (25) which concluded that CT was with higher sensitivity than RTG when diagnosing cases with OM. Rohleder et al. (18) compared the CT and RTG techniques to diagnose the presence and severity of the middle ear inflammation in dogs with chronic OE. They performed ear canal ablation in 31 dogs with chronic otitis concluding that CT was more accurate and reliable for the diagnosis of chronic and severe middle ear inflammation in the dogs, but highly variable with RTG in less severe cases.

In this study, the diagnosis of OM due to chronic OE (case 7) was made by using CT and RTG, easily visualizing the bilateral lesions in bulla tympanica. In case 8 , the radiopaque area in the left bulla tympanica visible on CT was not easily detectable on RTG. 


\section{CONCLUSION}

In conclusion, there are multiple imaging techniques available to diagnose ear inflammation in small animals and they should be used systematically. Although conventional radiographs can be obtained easily, the interpretation and sensitivity for diagnosing this condition are highly variable. Despite this, it is still a popular and useful method for the examination of dogs and cats with symptoms of ear disease. Nevertheless, the cross-sectional imaging with $\mathrm{CT}$ offers numerous advantages over RTG. It is highly useful for examining the middle and inner ear structures. MRI is a sensitive method to examine the inner ear and adjacent structures but it was not a subject of comparison in the current research. MRI could provide more detailed imaging that could contemplate CT and/or RTG findings.

\section{CONFLICT OF INTEREST}

The authors declare that there is no conflict of interest related to this article.

\section{ACKNOWLEDGEMENTS}

The authors gratefully acknowledge the Department of Surgery, Faculty of Veterinary Medicine, Selcuk University that supported this study.

\section{AUTHORS' CONTRIBUTIONS}

KP, HE and MA were responsible for drafting the work or revising it critically for important intellectual content, as well as for the approval of the final version. MY, ETA, EOU and NZ made substantial contributions to the work concept/design, acquisition and analysis/ interpretation of data.

\section{REFERENCES}

1. Hill, P.B., Lo, A., Eden, C.A. (2006). Survey of the prevalence, diagnosis and treatment of dermatological diseases in small animals in general practice. Vet Rec. 158(16): 533-539.

https://doi.org/10.1136/vr.158.16.533

PMid:16632525

2. Kamaljyoti, Sharma, A.K., Filia, G., Sharma, S. (2017). Studies on Malassezia infection in otitis external of dogs. J Anim Res. 7, 197-200. https://doi.org/10.5958/2277-940X.2017.00027.4
3. Cristina, R.T., Degi, J. (2013). Multiresistant Staphylococcus intermedius isolated from otitis externa in dogs and them human owners -A practical approach. Afr J Pharm Pharmacol. 7(20): 1351-1356. https://doi.org/10.5897/AJPP2013.3450

4. Parmar, J.J., Rao, N., Shah, A.I., Sadhu, D.B., Bhanderi, B.B., Pate, D.M. (2020). Clinical studies on ear infections, microbiological evaluation and therapeutic management in canines. Int $\mathrm{J}$ Curr Microbiol App Sci. 9(1): 1496-1501. https://doi.org/10.20546/ijcmas.2020.901.167

5. Taylor, M.A., Coop, R.L., Wall, R.L. (2007). Chapter 6: Parasites of dogs and cats. In: Veterinary parasitology, 3rd edition (pp. 356-458). Oxford: Blackwell Publishing Ltd.

6. Salib, F., Baraka, T.A. (2011). Epidemiology, genetic divergence and acaricides of Otodectes cynotis in cats and dogs. Vet World. 4, 109-112. https://doi.org/10.5455/vetworld.2011.109-112

7. Cole, L.K. (2004). Otoscopic evaluation of the ear canal. Vet Clin North Am Small Anim Pract. 34(2): 397-410.

https://doi.org/10.1016/j.cvsm.2003.10.004

PMid:15062615

8. Gotthelf, L.N. (2004). Diagnosis and treatment of otitis media in dogs and cats. Vet Clin North Am Small Anim Pract. 34(2): 469-487.

https://doi.org/10.1016/j.cvsm.2003.10.007

PMid:15062620

9. Sula, M.M., Njaa, B.L., Payton, M.E. (2013). Histologic characterization of the cat middle ear sickness and in health. Veterinary Pathol. 51(5): 951-967.

https://doi.org/10.1177/0300985813511125

PMid:24280942

10. Rosychuk, R.A.W. (2017). Otitis media in cats. Practical otitis workshop of the European society of veterinary dermatology. June, 1-3 (pp. 79-84), Vienna, Austria.

11. Foster, A., Morandi, F., May, E. (2014). Prevalence of ear disease in dogs undergoing multidetector thin-slice computed tomography of the head. Vet Radiol Ultrasound. 58(1): 18-24.

https://doi.org/10.1111/vru.12180

PMid:25046431

12. Angus, J.C., Lichtensteiger, C., Campbell, K.L., Schaeffer, D.J. (2002). Breed variations in histologic features of chronic severe otitis externa in dogs: 80 cases (1995-2001). J Am Vet Med Assoc. 221(7): $1000-1006$.

https://doi.org/10.2460/javma.2002.221.1000

PMid:12369678 
13. Saridomichelakis, M.N., Farmaki, R., Leontides, L.S., Koutinas, A.F. (2007). Aetiology of canine otitis externa: a retrospective study of 100 cases. Vet Dermatol. 18(5): 341-347.

https://doi.org/10.1111/j.1365-3164.2007.00619.x PMid:17845622

14. Stephan, F., Saade, D., Nasser, M. (2019). The importance of video otoscopy in the diagnosis and treatment of chronic otitis in dogs. Rev Vet Clin. 54(3-4): 95-102.

https://doi.org/10.1016/j.anicom.2019.09.008

15. Bloom, P. (2013). Diagnosis and management of otitis in the real world. WSAVA World Congress Proceedings. March, (pp. 6-9), Auckland, New Zealand.

16. Kennis, R.A. (2012). Feline otitis: diagnosis and treatment. Vet Clin North Am Small Anim Pract. 43(1): 51-56.

https://doi.org/10.1016/j.cvsm.2012.09.009

PMid:23182324

17. Arican, M. (2011). Chapter 2: Radiographic evaluation of the head and neck. In: Veterinary general radiology and atlas of diagnostic radiography for cat, dog (pp. 37-90). Konya: Bahcivanlar Inc. [In Turkish]

18. Rohleder, J.J., Jones, J.C., Duncan, R.B., Larson, M.M., Waldron, D.L., Tromblee, T. (2006). Comparative performance of radiography and computed tomography in the diagnosis of middle ear disease in 31 dogs. Vet Radiol Ultrasound. 47(1): 45-52. https://doi.org/10.1111/j.1740-8261.2005.00104.x PMid:16429984

19. Doust, R., King, A., Hammond, G., Cave, T., Weinrauch, S., Mellor, D., Sullivan, M. (2007). Assessment of middle ear disease in the dog: a comparison of diagnostic imaging modalities. JSAP. 48(4): 188-192.

https://doi.org/10.1111/j.1748-5827.2007.00295.x

PMid:17381763
20. King, A.M., Weinrauch, S.A., Doust, R., Hammond, G., Yam, P.S., Sullivan, M. (2007). Comparison of ultrasonography, radiography and a single computed tomography slice for fluid identification within the feline tympanic bulla. Vet J. 173(3): 638-644.

https://doi.org/10.1016/j.tvj1.2006.02.003

PMid:16580850

21. Tang, F.L., Yang, H.Q., Ma, X.W., Lu, D.Z. (2019). Epidemiological analysis of ear diseases in 221 dogs in northwest of China. bioRxiv, 541516. https://doi.org/10.1101/541516

22. Usui, R., Usui, R., Fukuda, M. (2009). Obstruction of ear canals in an American Cocker Spaniel successfully treated using a video otoscope. Jap J Vet Dermatol. 15(4): 207-210. https://doi.org/10.2736/jjvd.15.207

23. Remedios, A.M., Fowler, J.D., Pharr, J.W. (1991). A comparison of radiographic versus surgical diagnosis of otitis media. J Am Anim Hosp Assoc. 27(2): 183-188.

24. Hoskinson, J.J. (1993). Imaging techniques in the diagnosis of middle ear disease. Semin Vet Med Surg Small Anim. 8(1): 10-16.

25. Love, N.E., Kramer, R.W., Spodnick, G.J., Thrall, D.E. (1995). Radiographic and computed tomographic evaluation of otitis media in the dog. Vet Radiol Ultrasound. 36(5): 375-379. https://doi.org/10.1111/j.1740-8261.1995.tb00279.x

Please cite this article as: Parlak K., Yalcin M., Erol H., Akyol E.T., Uzunlu E.O., Zamirbekova N., Arican M. Evaluation of video-otoscopic, radiographic and computed tomographic examinations of cats and dogs with ear diseases. Mac Vet Rev 2021; 44 (1): 95-101. https://doi.org/10.2478/macvetrev-2021-0013 